\title{
Effectiveness of Replacing Inorganic Fertilizer with Compost Made of Garden Waste for Coconut Palm
}

\author{
Athambawa Samsar, Athamabwa Mohamed Razmy
}

\begin{abstract}
Replacement of inorganic fertilizer with organic manure is welcome by the world due to health concern and increasing cost of production. In the coconut sector, inorganic fertilizers are heavily used and it is costly. Therefore, three treatment combinations were tried to supplement or replace the inorganic fertilizer with the organic manure for the coconut palms. The study revealed that completely forgetting the inorganic fertilizer with the tested amount of organic manure is not possible. Addition of organic manure to the existing inorganic fertilizer dose recommendation is not increasing the nut's yield in number but the nut's quality.
\end{abstract}

Keywords: Inorganic fertilizer, Nut's quality, Nut Yield, Organic Manure.

\section{INTRODUCTION}

$\mathrm{H}_{\text {igh dose of inorganic fertilizer application is a very }}$ common practice in coconut cultivation in Sri Lanka. This leads to several environmental hazards and the fertilizer cost is the major burden for the poor farmers. The cost of fertilizer has increased tremendously over the last few decades and still it is in increasing trend [1]. Therefore, the coconut cultivation in this Sri Lanka becomes a large investment for the farmers. To overcome this, the government has introduced fertilizer subsidy schemes. The subsidy payment constitutes 2.24 percent of total government expenditures and has become a massive burden on the Treasury [2]. In other hand there is a substantial increase in the quantity imported under the subsidy scheme due to enhanced demand for fertilizer. In the meantime, fertilizer subsidy is a very strong political issue in Sri Lanka [3]. National average yields of coconut have been stagnating over the last decade requiring a new approach to increase the national yield levels [4]. Reasons for such problem may be due to declining of organic matter content, imbalance of major plant nutrients and inadequacy of various micronutrients. These factors have adversely affected the overall soil fertility in cultivated lands in Sri Lanka. Soil organic matter content is one of the key parameters which

Revised Manuscript Received on March 13, 2020.

* Correspondence Author

Athambawa Samsar*, Department of Landscape, South Eastern University of Sri Lanka. E-mail: samsar@seu.ac.lk

Athamabwa Mohamed Razmy, Department of Applied Sciences, South Eastern University of Sri Lanka. Department of Statistics, Sultan Qaboos University, Sultanate of Oman.E-mail: amrazmy@seu.ac.lk,

(C) The Authors. Published by Blue Eyes Intelligence Engineering and Sciences Publication (BEIESP). This is an open access article under the CC BY-NC-ND license (http://creativecommons.org/licenses/by-nc-nd/4.0/) influence the soil fertility and productivity. However, it should be noted that increasing the organic matter in soils is a difficult task due to prevailing high temperature in many parts of the country. In this regard, the seasonal applications of organic materials are necessary. By considering all these factors, possibility of replacing the inorganic fertilizers with compost made of garden waste for coconut cultivation may be a viable solution. Therefore, in this study, an attempt for partly or fully replacing the inorganic fertilizer with Compost made of garden waste is tried.

\section{METHODOLOGY}

Four fertilizer treatments were tested on the 16 adult coconut palms (Cocus nucifera L. Var. typica - tall) each with 15 years old in the South Eastern university coconut garden. The selected treatments for this study are given in the Table I. The adult palm mixture contains the inorganic fertilizer in the ratio of $\mathrm{N}$ : P: $\mathrm{K}$ as 16:6:32. These fertilizer mixtures were applied continuously in six months intervals.

Table-I. The Treatments Tested

\begin{tabular}{|c|c|c|c|}
\hline Treatment & $\begin{array}{c}\text { Adult } \\
\text { Palm } \\
\text { Mixture } \\
\text { (kg/ tree) }\end{array}$ & $\begin{array}{c}\text { Coir dust } \\
\text { (kg/ tree) }\end{array}$ & $\begin{array}{c}\text { Compost } \\
\text { (kg/ tree) }\end{array}$ \\
\hline T1 & 5 & 10 & 0 \\
\hline T2 & 5 & 10 & 20 \\
\hline T3 & 5 & 10 & 25 \\
\hline T4 & 0 & 10 & 25 \\
\hline
\end{tabular}

Compost was made according to the method discussed in the razmy et.al in 2009 [5]. Dry leaves were collected inside the university premises and heaped. Water was sprayed on the heap in 5 days interval. Urea granules were added to heap after 5 days of making heap. This heap was mixed every 2 weeks. The molted leafs were transferred to a pit in 5 weeks and turned every 2 weeks. The compost was ready in 12 weeks for use. The figures 1 shows the compost making process. The design used for this experiment is randomized complete block design with four blocks. Trees were blocked across the girth diameter.

Published By:

Blue Eyes Intelligence Engineering \& Sciences Publication 
The average yield records of each palm in term of number of nuts before starting the experiment in four consecutive plucking $\left(\bar{Y}_{i j B}\right)$ and the average yield records of each palm after one year of starting the experiment, in four consecutive plucking $\left(\bar{Y}_{i j A}\right)$ were obtained. The difference in yield for each palm $\left(d \bar{Y}_{i j}=\bar{Y}_{i j A}-\bar{Y}_{i j B}\right)$ was calculated and used as response variable in terms of number of nuts.

In the same way, average yield records for each palm in term of weights of nuts before starting the experiment in the four consecutive plucking $\left(\bar{W}_{i j B}\right)$ and the average yield records for each palm after one year of starting the experiment, in four consecutive plucking $\left(\bar{W}_{i j A}\right)$ were obtained. The difference in yield for each palm $\left(d \bar{W}_{i j}=\bar{W}_{i j A}-\bar{W}_{i j B}\right)$ was calculated and used as response variable in terms of weights of the nuts. Before starting the experiment, these all selected 16 palms were applied with the fertilizer as in the treatment - I in six months interval. The obtained data were analyzed using a two-way ANOVA.
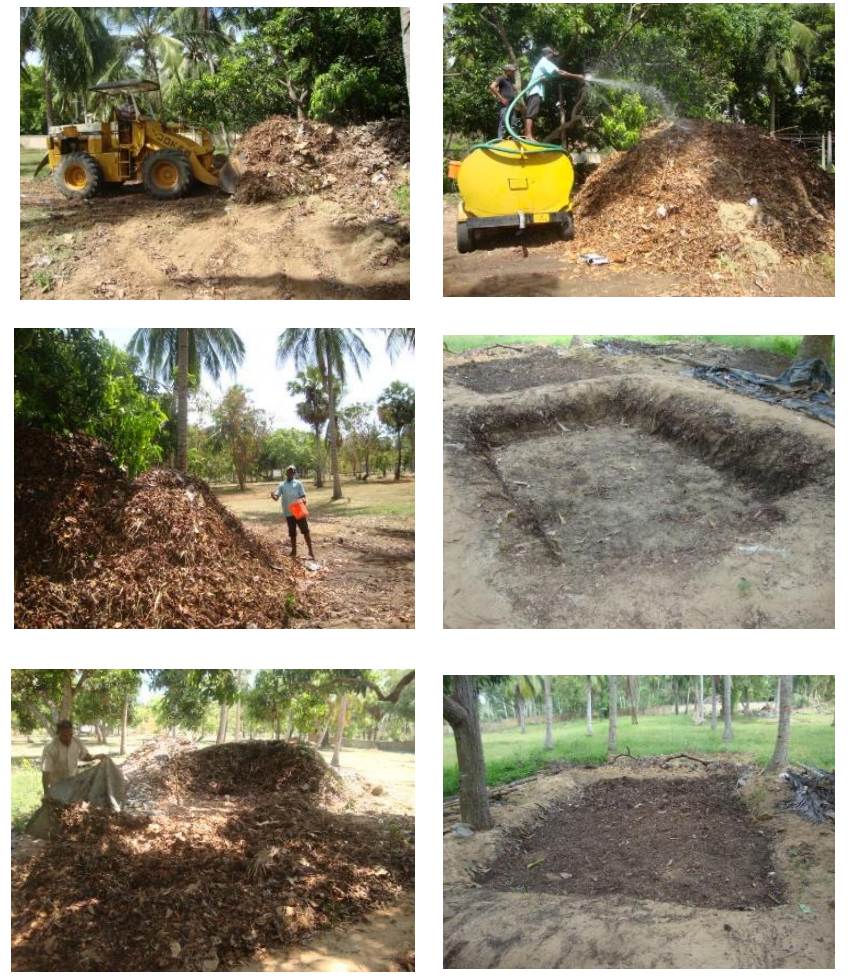

Figure 1 Compost making process

\section{RESULTS}

The recorded $d \bar{Y}_{i j}$ were analyzed and it was found from the ANOVA table that at least one type of treatment gives different nut yield from the other treatments $(p=0.001)$. The average

$d \bar{Y}_{i j}$ values were $0.875,1.375,1.250$ and -2.750 nuts per plucking for the treatments $1,2,3$ and 4 respectively. The grand average difference for the $1^{\text {st }}$ treatment $\left(d \overline{\bar{Y}}_{1}\right)$ is 0.875 nuts per plucking and it is not significantly differing from zero $(p=0.001)$. Even though the difference for the $2^{\text {nd }}$ and $3^{\text {rd }}$ treatments $\left(d \overline{\bar{Y}}_{2}\right.$ and $\left.d \overline{\bar{Y}}_{3}\right)$ are significantly higher than zero, these values are not differs from the grand average difference for the $1^{\text {st }}$ treatment $\left(d \overline{\bar{Y}}_{1}\right)_{(\mathrm{p}=0.001)}$. Therefore, addition of organic manure (in the treatments 2 and 3 ) to the existing inorganic fertilizer has not significantly increased the nuts yield in numbers $(\mathrm{p}=0.001)$. But replacing the inorganic fertilizer with organic manure quantity given in treatment 4 has reduced the yield significantly by 2.75 nuts per plucking $(p=0.001)$. The relevant ANOVA table and the mean comparisons for this analysis are given in Table II and III respectively.

Table-II. Two-way ANOVA for Difference in Nuts Yield in Numbers

\begin{tabular}{|lclcll|}
\hline Source & DF & SS & MS & F & P \\
\hline Treatment & 3 & 46.5625 & 15.5208 & 16.31 & 0.001 \\
\hline Block & 3 & 3.8125 & 1.2708 & 1.34 & 0.323 \\
\hline Error & 9 & 8.5625 & 0.9514 & & \\
\hline Total & 15 & 58.9375 & & & \\
\hline
\end{tabular}

Table-III. Mean Comparisons for the Difference in Nuts Yield in Numbers

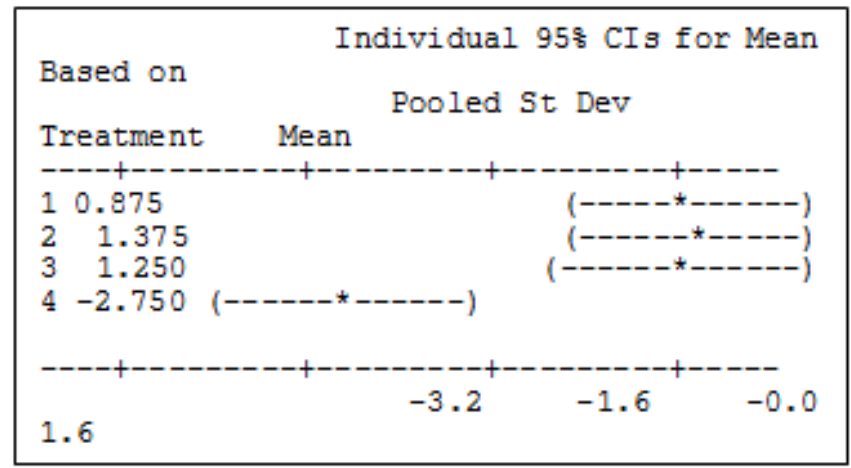

The recorded average weight difference $d \bar{W}_{i j}$ are giving the results that at least one type of treatment gives different weight from the other treatments $(p=0.004)$. The average $d \bar{W}_{i j}$

$i j$ values were $1.0,94.5,116.8$ and -42.75 grams for the treatments 1,2,3 and 4 respectively. The grand average difference for the $1^{\text {st }}$ treatment $\left(d \bar{W}_{1}\right)$ is 1 gram and it is not significantly difference from zero $(p=0.001)$. The differences for the $2^{\text {nd }}$ and $3^{\text {rd }}$ treatments $\left(d \bar{W}_{2}\right.$, and $\left.d \bar{W}_{3 .}\right)$ are significantly higher than the $d \bar{W}_{1}$. Therefore, the addition of organic manure in the treatments 2 and 3 with the inorganic manure has significantly increased the nut's weight $(p=.05)$. But replacing the inorganic fertilizer with organic manure quantity given in treatment 4 has reduced the nut's weight significantly by 42.75 grams $(\mathrm{p}=0.05)$. The relevant ANOVA table and the mean comparisons for this analysis of nuts' weight is given in Table IV.

Published By:

Blue Eyes Intelligence Engineering \& Sciences Publication

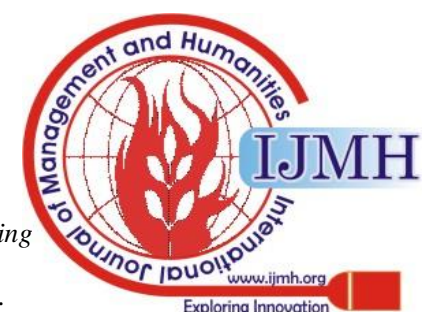


Table-IV. Two-way ANOVA for Difference in Nuts Yield Weights

\begin{tabular}{|lrrrrr|}
\hline Source & DF & SS & MS & F & P \\
\hline Treatment & 3 & 68827.3 & 22942.4 & 9.57 & 0.004 \\
\hline Block & 3 & 6916.3 & 2305.4 & 0.96 & 0.452 \\
\hline Error & 9 & 21576.3 & 2397.4 & & \\
\hline Total & 15 & 97319.8 & & & \\
\hline
\end{tabular}

\section{DISCUSSION}

In this study limited amount of organic manure addition were tested, and it will be good if more combination were tested. Amount of coconut oil extraction and the oil quality can be another output measure [6] and this is not analyzed in this study. The other output variables can be coconut sugar [7] and the husk [8] and these could be analyzed for the amount of production and quality in future.

\section{CONCLUSION}

The study concludes that addition of organic manure in the said quantities in the treatments 2 and 3 to the exiting amount of inorganic fertilizer and applying to the coconut palms has not significantly increased the yield. Therefore, in the economical point of view, when selling the nuts in numbers, the addition of organic manure will add an additional cost without increasing the income. But the said process has significantly increased the nut's weight. The treatment 2 and 3 increase the quality of the nuts by increasing the average weight. If the farmers are selling the nuts by weight, adding the organic manure with the inorganic manure will increase their income. For example, in the treatment 2, the additional organic manure applying cost will be SLRS. 450.00 per year and this cost will increase the income by $472.50 \mathrm{X}$ price of nut/gram per year.

\section{REFERENCES}

1. Wijewardena, J.D.H., Improvement of plant nutrient management for better farmer livelihood, food security and environment in Sri Lanka. Improving plant nutrient management for better farmer livelihoods, food security and environmental sustainability, Beijing, China, 12-16 December 2005; Food and agriculture organization of the United Nations regional office for Asia and the Pacific, Bangkok, 2006, 5.

2. Weerahewa, J., S.S. Kodithuwakku, and A. Ariyawardana. 2010. The Fertilizer Subsidy Program in Sri Lanka. In Food policy for developing countries: Case studies, ed. P. Pinstrup-Andersen and F. Cheng. Ithaca: Cornell University. Retrieved December 16, 2019, from http://www.indiaenvironmentportal.org.in/files/fertiliser\%20sub sidy\%20 programme\%20in\%20sri\%20lanka.pdf.

3. Abeygunawardane, D.V. Why is the Subsidy on Fertilizers for Rice in Sri Lanka Continued? PhD Thesis, The University of Queensland, Australia, 2014.

4. Sepala, A.C.K, Socio-economic conditions of coconut small -holding sector in Sri Lanka Agrarian research and training institute, Sri Lanka, 1986.

5. Razmy AM, Ahmed AN \& Iqbal YB (2009), A Remedy for the Problems Caused by Eichorniacrassipes in the Ampara District, CIDA restore project Wrap-up Conference 2009, Kandy

6. Ruangyote Pilajun, Metha Wanapat, Chalong Wachirapakorn and Chainarong Navanukroaw, 2010. Effect of Coconut Oil and Sunflower Oil Ratio on Ruminal Fermentation, Rumen Microorganisms, N-balance and Digestibility in Cattle. Journal of Animal and Veterinary Advances, 9: 1868-1874. DOI: $10.3923 /$ javaa.2010.1868.1874

7. Suliyanto , 2013. Financing Model of Coconut Sugar Micro Small and Medium Entreprises (MSMEs) in Indonesia. International Business Management, 7: 410-413. 10.36478/ibm.2013.410.413

8. E.A. Aziz, A.S. Abdul Razak, S. Sulaiman, H.A. Halim, Mir Sujaul Islam, N.A. Zainodin and W.A. Wan Omar, 2016. The Performance of
Coconut Husk and Shell for the Removal of Methyl Red from Aqueous Solution: Adsorption Equilibrium and Kinetic Study. Journal of Engineering and Applied Sciences, 11: 2500-2507. DOI: $\underline{10.36478 / \text { jeasci.2016.2500.2507 }}$

\section{AUTHORS PROFILE}

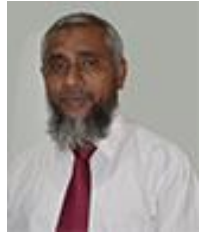

Mr. Athambawa Samsar, received his Masters in Environmental Economics and Postgraduate Diploma in Landscape Design and B.Sc in Agricultural Science. He is working as a Curator/Landscape and having 22 years' experience in Landscaping Design at the Department of Landscape, South Eastern University of Sri Lanka. His research interest include Sustainable Agriculture and Sustainable Landscape

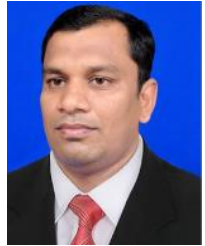

Dr. Athambawa Mohamed Razmy, received Ph.D degree in Statistics. He is having 22 years teaching experience and has published more than 50 research findings. He is working as Senior Lecturer in Statistics at faculty of Applied Sciences, South Eastern university of Sri Lanka. His service is also rendered as Assistant Professor to the Sultan Qaboos University, Sultanate of Oman. His research interest includes Quality control, Design of Experiments and Clinical trials. 